九州大学学術情報リポジトリ

Kyushu University Institutional Repository

\title{
Rapid Identification of Phytopathogenic Bacteria by TLC
}

Khan, Abu Ashraf

Laboratory of Plant Pathology, Faculty of Agriculture, Kyushu University

Matsuyama, Nobuaki

Laboratory of Plant Pathology, Faculty of Agriculture, Kyushu University

https://doi.org/10.5109/24214

出版情報：九州大学大学院農学研究院紀要. 42 (3/4)，pp.281-287，1998-03. Kyushu University バージョン：

権利関係 : 


\title{
Rapid Identification of Phytopathogenic Bacteria by TLC
}

\author{
Abu Ashraf Khan and Nobuaki Matsuyama \\ Laboratory of Plant Pathology, Facuity of Agriculture, \\ Kyushu University, Fukuoka 812-8581, Japan \\ (Received October 23, 1997 and accepted December 3, 1997)
}

\begin{abstract}
A rapid identification by TLC was performed for phytopathogenic bacteria (Burkholderia spp., Ralstonia solanacearum and Herbaspirillum mubrisubalbicans). One loopful bacterial cell was suspended in $0.2 \mathrm{ml}$ of chloroform-methanol $(2: 1, \mathrm{v} / \mathrm{v})$ in a small glass-vial and kept for $15 \mathrm{~min}$ in room temperature. About $10 \mu \mathrm{l}$ of lipid extract was spotted on the origin of silica gel TLC plate and dried well. The plate was developed with chloroform-methanol- $0.2 \%$ calcium chloride $(55: 35: 8, \mathrm{v} / \mathrm{v} / \mathrm{v})$ for $1 \mathrm{hr}$ at $25^{\circ} \mathrm{C}$. After drying, the spots were visualized by spraying ninhydrin and successive heating at $100^{\circ} \mathrm{C}$ for $10 \mathrm{~min}$. The chromatograph was recorded by a photograph and/or photocopy. The lipid spots appeared on TLC plate at $R f(0.42-0.83$ area were reliable benchmarks for differentiation of rRNA homology group II pseudomonads. The chromatograms of Burkholderia caryophylli, B. cepacia, B. gladioli, B. glumae, B. plantarii and $B$. vandii resembled each other but were distinct at species level and clearly different from $R$. solanacearum, B. andropogonis and $H$. rubrisubalbicans. The chromatographs of $B$. andropogonis and $R$. solanacearum were found roughly similar, but characteristic spots at Rf 0.42-0.52 region were absent in $R$. solanacearum. On the other hand, the profile of $H$. rubrisubalbicans was quite unique. This TLC method will be practical for rapid identification of phytopathogenic bacteria.
\end{abstract}

\section{INTRODUCTION}

The identification of phytopathogenic bacteria usually requires a series of physiological and biochemical tests under a determinative scheme and a host pathogenicity tests. These all tests are time consuming and in some cases difficult to interpret the results. Recently, chemotaxonomy has been introduced in systematic taxonomy and identification of bacteria by cellular fatty acid analyses has been well established (Chase et al., 1992; De Boer and Sasser, 1986; Ikemoto et al., 1978; Kori et al., 1992; Roy, 1988). However, this method needs facilities and preparation of samples are time consuming.

The direct colony TLC for lipid identification was firstly invented by Matsuyama $e t$ al. (1986) and applied successfully for rapid identification of phytopathogenic bacteria (Matsuyama et al., 1993a, b, c; Matsuyama and Furuya, 1993; Matsuyama, 1995a,b). This method, however, needs about 1-2 hr for drying the bacterial colony on TLC plate before development and requires two times developments in two different solvent systems. The modification of original direct colony TLC method was conducted and results were presented in this report. 


\section{MATERIALS AND METHODS}

\section{Bacterial strains}

Thirty one isolates of Burkholderia spp., Ralstonia solanacearum and Herbaspirillum rubrisubalbicans (all were formerly rRNA homology group II pseudomonads) were tested in this experiment. The details of the isolates were given in Table 1.

Table 1. List of bacterial isolates used in this study.

\begin{tabular}{|c|c|c|}
\hline Phytopathogenic bacteria & Isolate & Source \\
\hline \multirow[t]{2}{*}{ Burkholderia caryophylli } & NIAS 1192 & NIAS \\
\hline & NLAS 1406 & NIAS \\
\hline \multirow[t]{4}{*}{ B. cepacia } & ATCC $25416^{\mathrm{T}}$ & ATCC \\
\hline & $343-4$ & NIAS \\
\hline & $356-3$ & NIAS \\
\hline & $356-5$ & NIAS \\
\hline \multirow[t]{4}{*}{ B. gladioli pv. gladioli } & ATCC $10248^{\top}$ & ATCC \\
\hline & NIAS 1065 & NIAS \\
\hline & $\mathrm{E}-14$ & AKU \\
\hline & MAFF 302515 & NIAR \\
\hline B. gladioli pv unidentified & MAFF 302418 & NIAR \\
\hline \multirow[t]{5}{*}{ B. glumae } & MAFF $301169^{\mathrm{T}}$ & NIAR \\
\hline & 2 & KNAES \\
\hline & N 7504 & NIAS \\
\hline & N 7501 & NIAS \\
\hline & Куи 82-34-2 & KNAES \\
\hline \multirow[t]{3}{*}{ B. plantarii } & MAFF $301723^{\mathrm{T}}$ & NIAR \\
\hline & MAFF 302387 & NIAR \\
\hline & MAFF 302484 & NIAR \\
\hline B. vandii & JCM $7957^{\top}$ & JCM \\
\hline \multirow[t]{2}{*}{ B. andropogonis } & MAFF 301006 & NIAR \\
\hline & MAFF 301129 & NIAR \\
\hline \multirow[t]{2}{*}{ Herbaspirillum rubrisubalbicans } & MAFF 301626 & NIAR \\
\hline & MAFF 301628 & NIAR \\
\hline \multirow[t]{7}{*}{ Ralstonia solanacearum } & ATCC $11696^{\mathrm{T}}$ & ATCC \\
\hline & C 319 & KTES \\
\hline & 8107 & NRIV \\
\hline & 8224 & NRIV \\
\hline & 6511 & NIAS \\
\hline & $\mathrm{Ku} 7502-1$ & AKU \\
\hline & 855 & UNB \\
\hline
\end{tabular}

NIAS: National Institute of Agricultural Sciences, Tokyo, Japan.

ATCC: American Type Culture Collection.

AKU: Faculty of Agriculture, Kyushu University, Fukuoka, Japan.

NIAR: National Institute of Agricultural Resources, Tsukuba, Japan.

KNAES: Kyushu National Agricultural Experiment Station, Kumamoto, Japan.

JCM: Japan Collection of Microorganisms, Saitama, Japan.

KTES: Kagoshima Tobacco Experiment Station, Japan.

NRIV: National Reasearch Institule of Vegetable, Ornamental Plant and Tea

Morioka Branch, Japan.

UNB: University of Brasilia, Brasilia, Brazil

Type culture: Small T at the shoulder of isolate number indicated type culture. 


\section{Growth conditions}

Each culture was grown on a slant of King's $\mathrm{B}$ agar medium (20.0 g peptone, $1.5 \mathrm{~g}$ $\mathrm{K}_{2} \mathrm{HPO}_{4}, 1.5 \mathrm{~g} \mathrm{MgSO}_{4} \cdot 7 \mathrm{H}_{2} \mathrm{O}, 15.0 \mathrm{~g}$ agar, 1 liter of $1 \%$ glycerol solution, $\mathrm{pH} 7.2$, Eiken Chem. Co.) at $30^{\circ} \mathrm{C}$ for 3 days.

\section{Lipid extraction}

One loopful bacterial cell was placed in a small glass vial and $0.2 \mathrm{ml}$ of chloroformmethanol solution $(2: 1, \mathrm{v} / \mathrm{v})$ was added and the vial was capped tightly. Bacterial cells were mixed gently and kept for $15 \mathrm{~min}$ at room temperature.

\section{Thin-layer chromatography}

About $10 \mu \mathrm{l}$ of lipid extract was spotted on the origin of pre-coated silica gel TLC plate (Merck Co. Si 60, $0.25 \mathrm{~mm}$ in thickness) and completely dried by a hair drier. Sample spots were placed aparting $1.5 \mathrm{~cm}$ each other at a distance of $1.0 \mathrm{~cm}$ from the bottom edge of the plate. The plate was developed with chloroform-methanol- $0.2 \%$ calcium chloride $(55: 35: 8, \mathrm{v} / \mathrm{v} / \mathrm{v})$ solvent system for $1 \mathrm{hr}$ and dried well. The development was conducted in an incubator at $25^{\circ} \mathrm{C}$.

\section{Detection of spots}

Detection of the spots on TLC plate was performed by spraying ninhydrin (Ninhydrin spray, .Tokyo Kasei Chem. Co.) followed by heating in an oven at $100^{\circ} \mathrm{C}$ for $10 \mathrm{~min}$. The spraying of sulfuric acid-dichromate $\left(0.6 \% \mathrm{~K}_{2} \mathrm{Cr}_{2} \mathrm{O}_{7}\right.$ in $\left.50 \% \mathrm{H}_{2} \mathrm{SO}_{4}\right)$ followed by heating at $130^{\circ} \mathrm{C}$ for $15 \mathrm{~min}$ was also conducted for visualizing of the spots of some pseudomonads. The chromatograms were recorded by photograph and/or photocopy.

\section{RESULTS}

The chromatographic profiles of Burkholderia spp., Ralstonia solanacearum and Herbaspirillum rubrisubalbicans were shown in Figs. 1 and 2. Distinct differences were found among the chromatographic profiles at species level. There were three benchmark spots, $S_{1}, S_{2}$ and $S_{3}$ (Fig. 1,2) under the common spot (Rf 0.76) represented well the characteristics of each species. The existence and relative size of the spots were species specific. In $B$. caryophylli, spot $\mathrm{S}_{2}$ was larger than spots $\mathrm{S}_{1}$ and $\mathrm{S}_{3}$, whereas spot $\mathrm{S}_{1}$ was larger than $\mathrm{S}_{2}$ and $\mathrm{S}_{3}$ in the case of $B$. cepacia. The chromatograms of $B$. gladioli, $B$. glumae, B. plantarii and B. vandii resembled each other. However, spots $\mathrm{S}_{1}$ and $\mathrm{S}_{3}$ were larger than $\mathrm{S}_{2}$ in $B$. gladioli and $B$. glumae. Again, spot $\mathrm{S}_{2}$ was slightly prominent in $B$. gladioli than that of $B$. glumae. $B$. plantarii and $B$. vandii were not distinguishable, where spot $S_{3}$ was larger than spots $S_{1}$ and $S_{2}$ (Fig. 1,2).

The chromatograms of $B$. andropogonis and $R$. solanacearum were similar at $\mathrm{Rf}$ $0.62-0.76$ area but differences were observed at $\mathrm{Rf} 0.42-0.52$. Characteristic spots at $\mathrm{Rf}$ $0.42-0.52$ area were absent in $R$. solanacearum. A spot at $\mathrm{Rf} 0.90$ was also detected in $B$. andropogonis by spraying with sulfuric acid-dichromate but was not detected in $R$. solanacearum.

The profile of chromatograms of $H$. mubrisubalbicans was very special, where spots $\mathrm{S}_{1}, \mathrm{~S}_{2}$ and $S_{3}$ were absent but a spot at $\mathrm{Rf} 0.83$ appeared along with the common spot at Rf 0.76 (Fig. 2). 


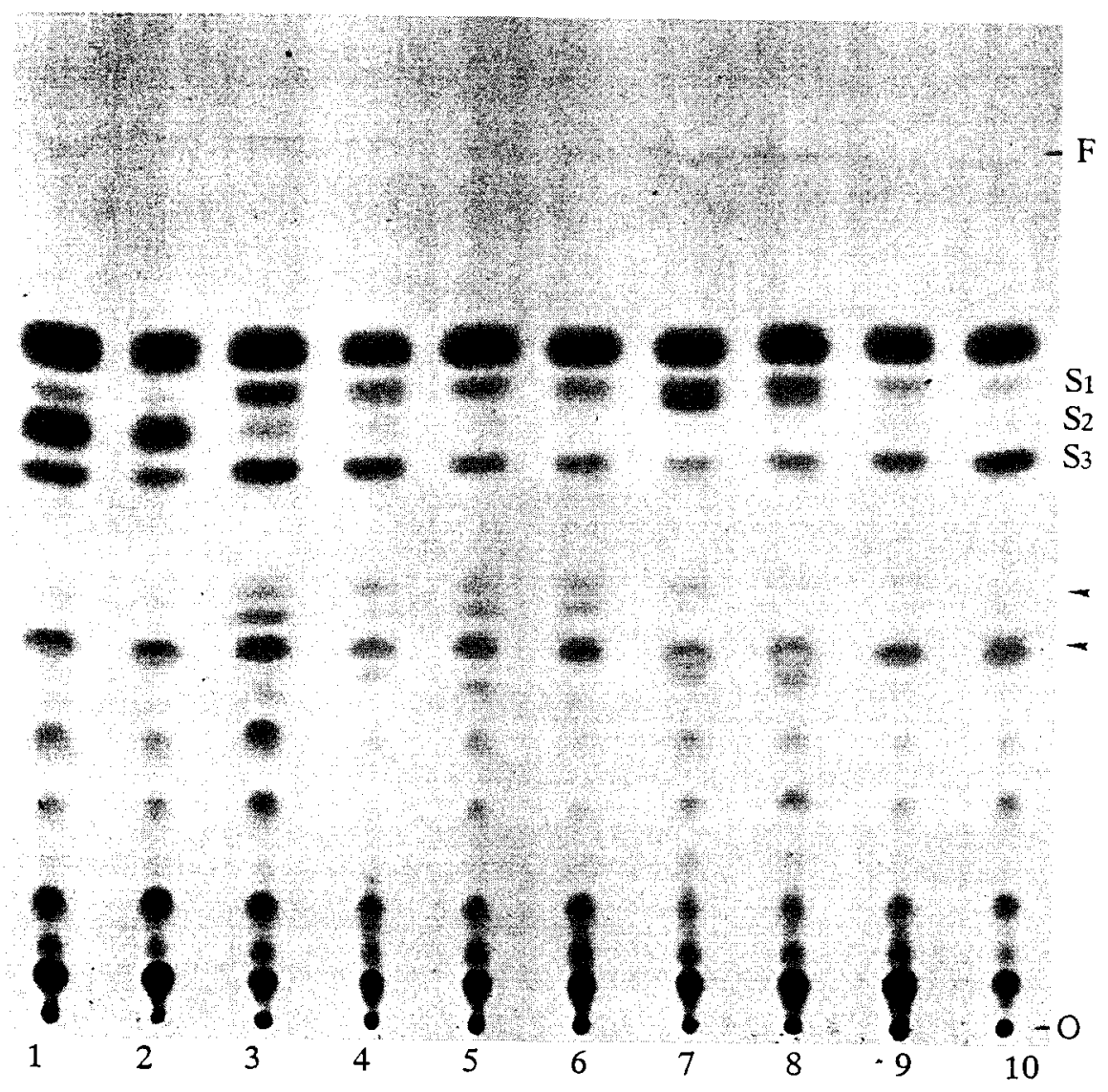

Fig. 1. TLC chromatograms of lipids from phytopathogenic bacteria.

1. B. caryophylli NIAS 1192

2. B. caryophylli NIAS 1406

3. B. gladioli pv. gladioli ATCC10248

4. B. gladioli pv. unidentified MAFF 302418

5. B. glumae MAFF $301169^{\mathrm{T}}$

6. B. glumae Kyu $82-34-2$

7. B. cepacia ATCC $25416^{\mathrm{T}}$

8. B. cepacia 356-5

9. B. plantarii MAFF301723'

10. B. plantari $\mathrm{MAFF} 302387$

F: Solvent front, $O$ : Origin

Double arrow heads indicate Rf $0.42-0.52$ 


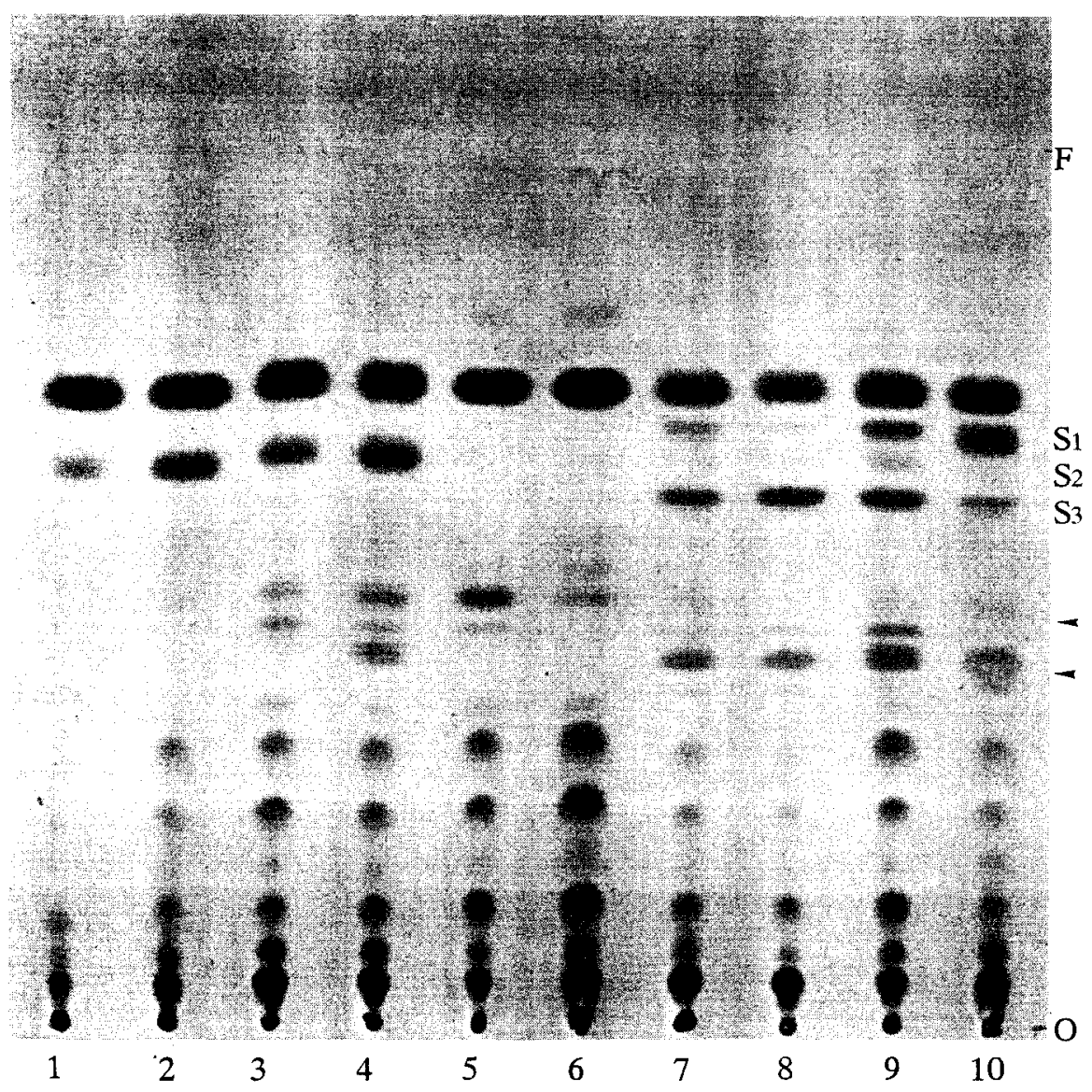

Fig. 2. TLC chromatograms of lipids from phytopathogenic bacteria.

1. R. solanacearum ATCC11696 ${ }^{\mathrm{T}}$

2. R. solanacearum C 319

3. B. andropogonis MAFF 301006

4. B. andropogonis MAFF 301129

5. H. rubrisubalbicans MAFF 301626

6. H. rubrisubalbicans MAFF 301628

7. B. plantarii MAFF301723

8. B. vandii JCM $7957^{\mathrm{T}}$

9. B. gladioli pv. gladioli ATCC10248

10. B. cepacia ATCC $25416^{\mathrm{T}}$

F: Solvent front, O: Origin

Double arrow heads indicate Rf $0.42-0.52$ 


\section{DISCUSSION}

Though lipid profile has not been used routinely in bacterial identification, extensive studies have shown their potential as taxonomic markers. Matsuyama et al. $(1986,1987)$ invented direct colony TLC for lipid analysis and used this method for identification of Serratia spp. The comparison of lipid profiles for rapid identification of phytopathogenic bacteria was performed by using the direct colony TLC (Matsuyama et al., 1993a,b,c; Matsuyama and Furuya, 1993; Matsuyama, 1995 a, b).

Since drying of the bacterial cells pasted on TLC plate was time consuming, modification of the direct colony TLC method was conducted. Bacterial lipid was extracted in a glass vial for only $15 \mathrm{~min}$ with chloroform-methanol solution $(2: 1, \mathrm{v} / \mathrm{v})$. Hence, the first development in the direct colony TLC for lipid extraction was avoided in the present method.

Among the strains used, chromatographic differences at species level were obviously observed and the species were distinguished on the basis of three benchmark lipid spots $\left(\mathrm{S}_{1}, \mathrm{~S}_{2}\right.$ and $\left.\mathrm{S}_{3}\right)$ appeared on TLC plate under the common spot at Rf 0.76 (Fig. 1, 2), and this result completely agreed with the former result (Matsuyama, 1995b). However, lipid spots appeared at Rf $0.42-0.52$ were also important benchmarks for some strains and these spots were not detectable by the original direct colony TLC (Matsuyama and Furuya, 1993; Matsuyama, 1995b). The chromatograms of the most members of Burkholderia such as B. caryophylli, B. cepacia, B. gladioli, B. glumae, B. plantarii and $B$. vandii resembled each other by lipid profiles but were clearly distinct from those of other strains which were also members of rRNA homology group $\mathbb{I}$ pseudomonads. This result also justified the proposal of transferring of $B$. caryophylli, B. cepacia, $B$. gladioli, B. glumae, B. plantarii and $B$. vandii into a new genus Burkholderia (Yabuuchi et al., 1992; Urakami et al., 1994). On the other hand, chromatograms of $B$. andropogonis and $R$. solanacearum were roughly similar. But lipid spots at Rf $0.42-0.52$ were absent in $R$. solanacearum. It also differed from other rRNA homology group II pseudomonads on the basis of these lipid spots. The lipid profile of $H$. rubrisubalbicans was quite unique. An unique profile of $H$. rubrisubalbicans was formerly reported (Matsuyama, 1995b) and the same result was confirmed also in the present solvent system. Stead (1992) reported that $H$. rubrisubalbicans and $R$. solanacearum could be differentiated from other rRNA homology group II pseudomonads on the basis of hydroxy fatty acid composition. These results were supported by the findings of our present lipid-TLC.

Thus, this simple lipid-TLC method is very practical and convenient for rapid identification and classification of phytopathogenic bacteria by comparison of lipid profiles.

\section{REFERENCES}

Chase, A. R., R. E. Stall, N. C. Hodge and J. B. Jones 1992 Characterization of Xanthomonas campestris strains from aroids using physiological, pathological and fatty acid analyses. Phytopathology, 82: 754-759

De Boer, S. H. and H. Sasser 1986 Differentiation of Erwinia carotovora spp. carotovora and $E$. carotovora spp. atroseptica on the basis of cellular fatty acid composition. Can. J. Microbiol., 32: 796-800

Ikemoto, S., H. Kuraishi, K. Komagata, R. Azuma, T. Suto and H. Muraoka 1978 Cellular fatty acid composition in Pseudomonas species. J. Gen. Appl. Microbiol, 24: 199-213

Kori, Y., N. Furuya, K. Tsuno and N. Matsuyama 1992 Differentiation of Erwinia chrysanthemi and E. 
carotovora by cellular fatty acid analysis. J. Fac. Agr, Kyushu Univ., 37: 173-178

Matsuyama, N., I. H. Mian, A. M. Akanda and N. Furuya 1993 a Application of the direct colony TLC method for identification of phytopathogenic bacteria. J. Fac. Agr., Kyushu Univ., 37(3, 4): $281-285$

Matsuyama, N., I. H. Mian, A. M. Akanda and N. Furuya 1993b Rapid identification of phytopathogenic bacteria by the direct colony thin-layer chromatography(1). Proc. Assoc., Pl. Prot. Kyushu, 39: 60-64

Matsuyama, N., I. H. Mian, A. M. Akanda and N. Furuya $1993 \mathrm{C}$ Comparative studies on thin-layer chromatograms of lipids from various phytopathogenic bacteria. Ann. Phytopath. Soc. Jpn, 59: 528-534

Matsuyama, N. and N. Furuya 1993 Application of the direct colony TLC for identification of phytopathogenic bacteria (II) Chromatographic profile of Erwinia and Pseudomonas spp. J. Fac. Agr., Kyushu Univ, $\mathbf{3 8}(1,2): 89-95$

Matsuyama, N. 1995a Trial for rapid identification of phytopathogenic bacteria by HPLC and the direct colony TLC. J. Fac. Agr, Kyushu Univ, $\mathbf{4 0}(1,2): 87-91$

Matsuyama, N. 1995b Application of the direct colony TLC for identification of phytopathogenic bacteria (III). Distinction of the pseudomonads in the rRNA-homology group II (Burkholderia spp.). J. Fac. Agr., Kyushu Univ., 40(1,2): 189-196

Matsuyama, T., M. Sogawa, K. Kaneda and I, Yano 1986 Rapid detection and identification of bacterial lipids by direct colony thin-layer chromatography. Proc. 23rd Int. Symp. Adv. Chromt, Chiba, Japan, pp 127-128

Matsuyama, T., M. Sogawa and I. Yano 1987 Direct colony thin-layer chromatography and rapid characterization of Serratia marcescens mutants defective in production of wetting agents. Appl. Environ. Microbiol., 53: 1186-1188

Roy, M. A. 1988 Use of fatty acids for the identification of phytopathogenic bacteria. Plant Disease, 72: 460

Stead, D. E. 1992 Grouping of plant-pathogenic and some other Pseudomonas spp. by using cellular fatty acid profiles. Int. J. Syst. Bacteriol, 42: 281-295

Urakami, T, C. Ito-Yoshida, H. Araki, T. Kajima, K. Suzuki and K. Komagata 1994 Transfer of Pseudomonas plantarii and Pseudomonas glumae to Burkholderia as Burkholderia spp. and description of Burkholderia vandii sp. nov., Int. J. Syst. Bacteriol., 44: 235-245

Yabuuchi, E., Y. Kosako, H. Oyaizu, 1. Yano, H. Hotta, Y. Hashimoto, T. Ezaki and M. Arakawa 1992 Proposal of Burkholderia gen. nov. and transfer of seven species of the genus Pseudomonas homology group $I$ to the new genus, with the type species Burkholderia cepacia (Palleroni and Holmes, 1981) comb. nov. Microbiol. Immunol., 36(12): 1251-1275 